\title{
Salinity Tolerance of Fertilized Eggs and Larval Survival in the Fish Sillago sihama*
}

\author{
C.-S. Lee ${ }^{* *}$, F. Hu and R. Hirano \\ Department of Fisheries, Faculty of Agriculture, The University of Tokyo, Bunkyo-ku, Tokyo 113, Japan
}

ABSTRACT: Salinity tolerance of fertilized eggs and larval survival of the fish Sillago sihama (Forskål) were compared using fertilized eggs from induced and natural spawnings, and eggs from adults acclimated to lower salinities. Fertilized eggs at the blastomere stage were more sensitive to salinity change than those at other development stages. Fertilized eggs from natural spawning were more tolerant to salinity change than those from induced spawning. Fertilized eggs from adults acclimated to lower salinities showed increased tolerance to lower salinities. Larvae survived longer in lower than in higher salinities.

\section{INTRODUCTION}

The fish Sillago sihama (Forskäl) is widely distributed throughout Japan (except Hokkaido), Korea, the southeastern coast of China, Taiwan, the Philippines, East Indies and Arabia, reaching as far as the Red Sea (Hiyama and Yasuda, 1961). In Japan, its good taste and attractive appearance make it one of the most important and valuable demersal fishes to both recreational and commercial fishermen. However, little is known about its early life stages. This paper reports and discusses the effects of salinity change on fertilized eggs and the survival of larvae after hatching. Three series of experiments were conducted on fertilized eggs obtained from induced spawning, natural spawning, or adults acclimated to low salinities. Survival rates were determined for larvae in different salinities.

\section{MATERIALS AND METHODS}

Series A: Spawners of Sillago sihama (Forskål) caught in Lake Hamana (Japan) in June were injected with a hormone (puberogen, 330 I. U.) and kept indoors in a spawning tank ( $2 \mathrm{~m}$ long $\times 1 \mathrm{~m}$ wide $\times 1 \mathrm{~m}$ deep) provided with seawater pumped from Lake Hamana $(27.2 \% \mathrm{~S})$. On the following night, the fertilized eggs

\footnotetext{
- Oceanic Institute Contribution No. 167

- Present address: Oceanic Institute, Makapuu Point, Waimanalo, Hawaii 96795, USA
}

were collected with a plankton net and transferred to 1-1 incubators at the blastomere, blastula, or pigmented-embryo stage. Two replicate incubators were used for each experimental treatment, each containing about 300 fertilized eggs in 0.91 water of test salinity at $24{ }^{\circ} \mathrm{C}$. Desired test salinities were obtained by diluting high-salinity seawater $(59 \% \mathrm{~S})$ - obtained by evaporating normal seawater - with distilled water. Seawater used in incubators was aerated before each treatment; the dissolved oxygen remained above $80 \%$ saturation in all treatments. All incubators were covered with transparent polyethylene wrap to decrease evaporation. The percentages of pigmented embryos and of hatching success were noted for each incubator in this and the subsequent series ( $B$ and $C$ ).

Se ries B: Fish obtained from Lake Hamana and reared in outdoor ponds for 9 months spawned spontaneously in $2 \mathrm{~m}$ long $\times 1 \mathrm{~m}$ wide $\times 1 \mathrm{~m}$ deep indoor spawning tanks at night during the spawning season. The salinity in spawning tanks was $28.9 \% \mathrm{~S}$. Fertilized eggs were collected and transferred to different salinities in 1-1 incubators containing 0.91 medium as before (Series A). Salinity change had little influence on development after the blastula stage (Series A). Therefore, in this series, the fertilized eggs were transferred only at the blastomere stage and kept at $24^{\circ} \mathrm{C}$.

$\mathrm{Series} \mathrm{C}$ : Wild fish were cultured indoors in a $3.45 \mathrm{~m}$ long $\times 1.65 \mathrm{~m}$ wide $\times 0.5 \mathrm{~m}$ deep concrete tank with a salinity of $28 \pm 1 \% \mathrm{~S}$ for 9 months. The mature fish were then transferred and held in a salinity of $17 \pm$ $1 \% \mathrm{~S}$ for $11 \mathrm{~d}$; subsequently, naturally spawned eggs were collected at the blastomere stage and transferred 


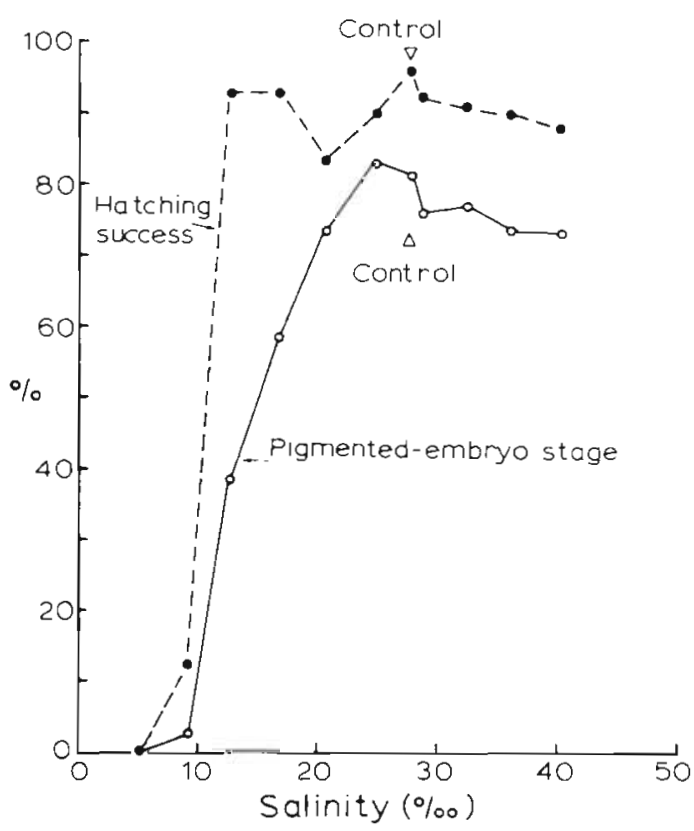

Fig. 1. Sillago sihama. Percentage of pigmented embryos and hatching success of inductively spawned eggs transferred from control $(27.2 \% \mathrm{~S})$ to different test salinities at the blastomere stage. Percentage hatching success refers to individuals reaching the pigmented-embryo stage

to different salinities in 1-1 incubators as described. The salinity in the spawning tank was $16.6 \% \mathrm{~S}$ at the time of transfer and the water temperature during incubation was about $25^{\circ} \mathrm{C}$.

Twenty larvae hatching in each salinity of Series A were transferred to two $100-\mathrm{cm}^{3}$ beakers, each containing water of the same salinity in which they were incubated, and held at about $23.8^{\circ} \mathrm{C}$. Live larvae were counted daily and transferred to new water of the same salinity. Food was withheld and survival was determined.

\section{RESULTS}

\section{Incubation of Eggs and Hatching Success}

Series A: $50 \%$ or more of the fertilized eggs, transferred at the blastomere stage, developed into pigmented embryos in the salinity range $16.8-40.2 \%$ $\mathrm{S}$; more than $80 \%$ of the embryos at the pigmented stage hatched successfully in 12.6-40.2\% S (Fig. 1). When the fertilized eggs were transferred at the blastula stage, no significant difference in the percentage of pigmented-embryo development was found in $5.2-48.5 \%$ S. Except in $5.2 \% \mathrm{~S}$, over $90 \%$ of the eggs reaching the pigmented-embryo stage hatched successfully (Fig. 2). $88 \%$ of the fertilized eggs, transferred at the blastula stage from the control $(28.2 \% \mathrm{~S})$ to a



Fig. 2. Sillago sihama. Percentage of pigmented embryos and hatching success of inductively spawned eggs transferred from control $(28.2 \%$ S) to different test salinities at the blastula stage. Percentage hatching success refers to individuals reaching the pigmented-embryo stage

salinity of $5.2 \% \mathrm{~S}$, developed into pigmented embryos, but failed to hatch (Fig. 2). Eggs transferred at the pigmented-embryo stage showed no significant differences in hatching success in 9.4-43.5\% $\mathrm{S}$ (Fig. 3). Pigmented embryos, transferred from the control $(29.7 \%$ S) to $5.7 \%$ S, failed to hatch (Fig. 3).

Series B: More than $85 \%$ of the naturally-spawned eggs developed into pigmented embryos, and al-

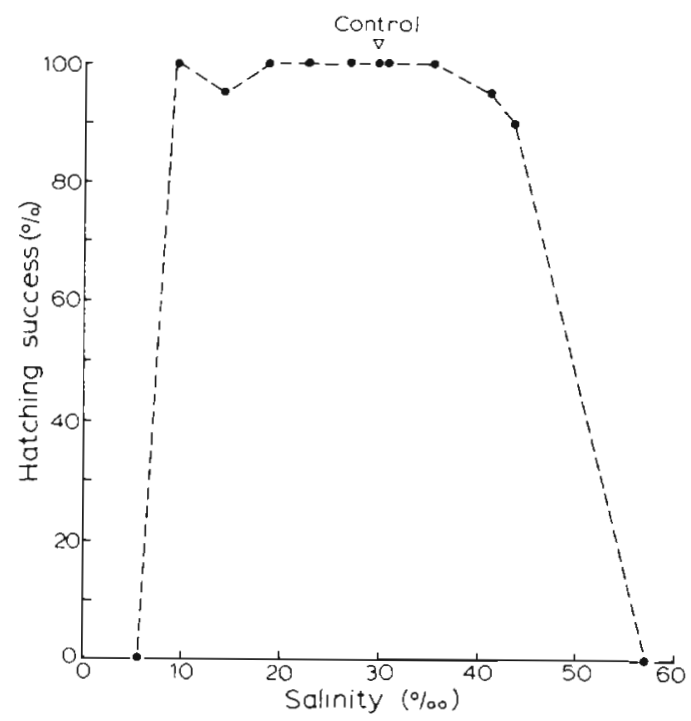

Fig. 3. Sillago sihama. Percentage hatching success of inductively spawned eggs transferred from control $(28.7 \%$ S) to different test salinities at the pigmented-embryo stage 


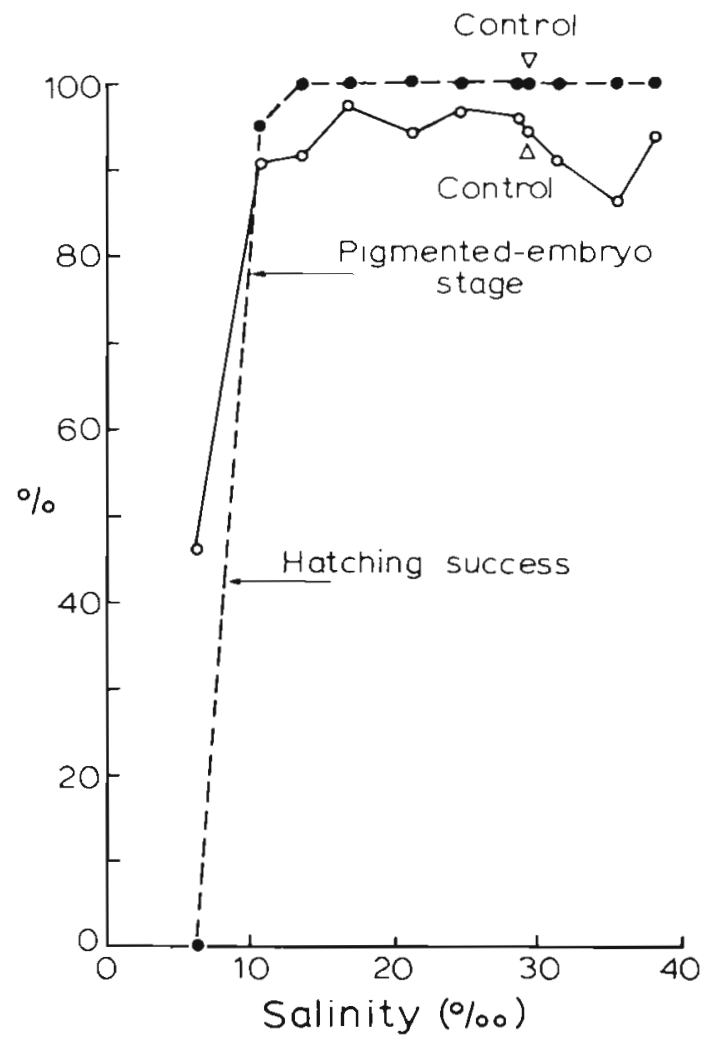

Fig. 4. Sillago sihama. Percentage of pigmented embryos and hatching success of eggs from natural spawning transferred from control $(28.9 \%$ S) to different test salinities at the blastomere stage. Percentage hatching success refers to individuals reaching the pigmented-embryo stage

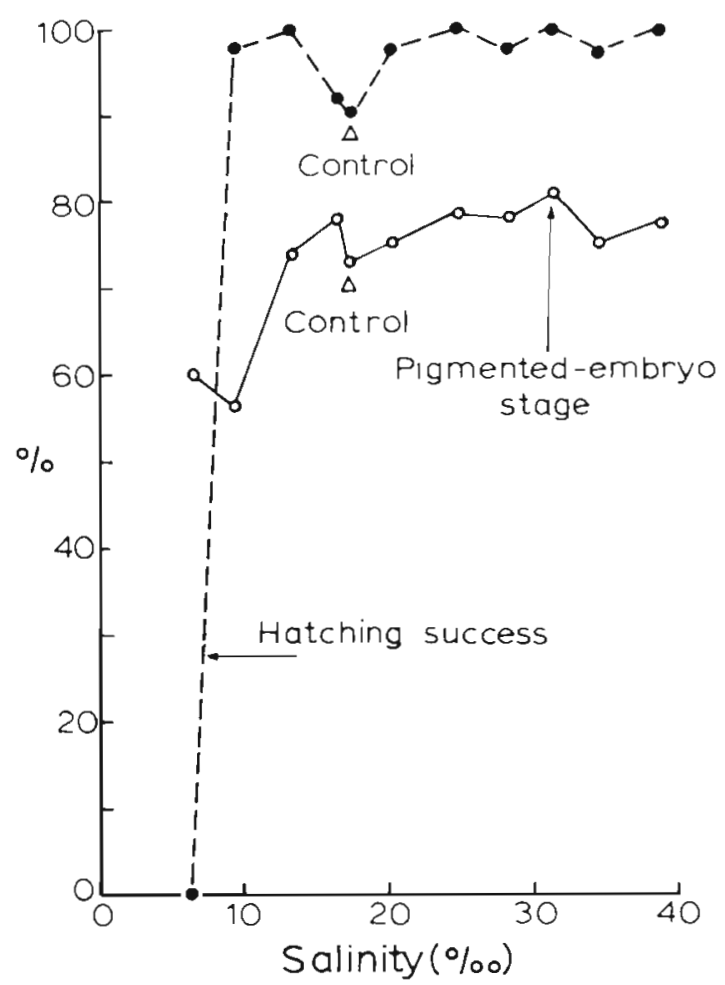

Fig. 5. Sillago sihama. Effect of low-salinity spawner-acclimation on the salinity tolerance of fertilized eggs transferred at blastomere stage (natural spawning). Control salinity: $16.6 \%$ S. Percentage hatching success refers to individuals reaching the pigmented-embryo stage

Table 1. Sillago sihama. Effect of salinity on larval survival under food deprivation (Series A). Fertilized eggs transferred to the different test salinities at the 2-blastomere stage

\begin{tabular}{|c|c|c|c|c|c|c|c|c|c|}
\hline $\begin{array}{c}\text { Days } \\
\text { after } \\
\text { hatching }\end{array}$ & 40.2 & 36.1 & 32.3 & 28.6 & $\begin{array}{c}\text { Salinity }(\%) \\
27.2 \\
\text { Control }\end{array}$ & 24.7 & 20.5 & 16.8 & 12.6 \\
\hline 1 & - & - & - & - & - & - & - & - & - \\
\hline 2 & 100.0 & 100.0 & 100.0 & 100.0 & 100.0 & 100.0 & 100.0 & 100.0 & 100.0 \\
\hline 3 & 92.5 & 100.0 & 94.5 & 100.0 & 92.4 & 100.0 & 100.0 & 94.7 & 90.2 \\
\hline 4 & - & - & - & - & - & - & - & - & - \\
\hline 5 & 0 & 2.5 & 2.5 & 0 & 41.1 & 2.5 & 15.0 & 23.7 & 39.4 \\
\hline 6 & 0 & 0 & 0 & 0 & 0 & 0 & 0 & 0 & 0 \\
\hline
\end{tabular}

Table 2. Sillago sihama. Effect of salinity on larval survival under food deprivation (Series A). Fertilized eggs transferred to the different test salinities at blastula stage

\begin{tabular}{|ccccccccccc|}
\hline $\begin{array}{c}\text { Days } \\
\text { after } \\
\text { hatching }\end{array}$ & 48.5 & 42.3 & 37.1 & 32.9 & $\begin{array}{c}\text { Salinity (\%o) } \\
28.2 \\
\text { Control }\end{array}$ & 23.6 & 18.6 & 14.0 & 9.2 \\
\hline 1 & 94.7 & 100.0 & 97.4 & 100.0 & 97.4 & 100.0 & 100.0 & 100.0 & 100.0 \\
2 & 66.7 & 100.0 & 97.4 & 94.7 & 89.5 & 94.9 & 93.0 & 98.0 & 84.2 \\
3 & 48.8 & 87.2 & 81.6 & 86.5 & 84.2 & 87.2 & 67.0 & 80.0 & 76.3 \\
4 & 48.8 & 71.4 & 68.4 & 81.0 & 84.2 & 77.1 & 61.8 & 70.0 & 60.5 \\
5 & 12.6 & 50.0 & 47.4 & 56.0 & 63.2 & 38.6 & 36.2 & 50.0 & 35.9 \\
6 & 0 & 2.5 & 5.3 & 34.1 & 42.1 & 30.7 & 23.2 & 20.0 & 18.0 \\
7 & 0 & 0 & 0 & 0 & 0 & 0 & 0 & 0 & 5.0 \\
\hline
\end{tabular}


Table 3. Sillago sihama. Effect of salinity on larval survival under food deprivation (Series A). Fertilized eggs transferred to the different test salinities at pigmented-embryo stage

\begin{tabular}{|c|c|c|c|c|c|c|c|c|c|c|}
\hline \multirow{3}{*}{$\begin{array}{c}\text { Days } \\
\text { after } \\
\text { hatching }\end{array}$} & \multicolumn{10}{|c|}{ Salinity $(\%)$} \\
\hline & 43.5 & 41.0 & 35.3 & 30.7 & 29.7 & 26.9 & 22.4 & 18.7 & 14.1 & 9.4 \\
\hline & \multicolumn{10}{|c|}{ Control } \\
\hline 1 & 94.7 & 98.0 & 98.0 & 98.0 & 93.0 & 98.0 & 100.0 & 100.0 & 77.8 & 100.0 \\
\hline 2 & 67.2 & 71.1 & 80.0 & 88.0 & 85.0 & 85.0 & 85.0 & 90.0 & 69.7 & 90.9 \\
\hline 3 & - & - & - & - & - & - & - & - & - & - \\
\hline 4 & 19.7 & 37.0 & 45.0 & 42.5 & 40.0 & 58.0 & 22.5 & 32.5 & 25.8 & 45.7 \\
\hline 5 & 0 & 0 & 0 & 0 & 0 & 0 & 0 & 7.5 & 7.5 & 20.0 \\
\hline
\end{tabular}

most all the pigmented embryos hatched successfully in 10.6-38.1\% $\mathrm{S}$ (Fig. 4).

Series C: Of the fertilized eggs, $60.3 \%$ developed into pigmented embryos in salinities as low as $6.2 \% \mathrm{~S}$ (Fig. 5); this percentage was higher than that obtained in Series A and B (Figs 1 and 4) where there was no acclimation of spawners to lower salinities. However, none of the embryos hatched successfully in the $6.2 \% \mathrm{~S}$ (Fig. 5).

\section{Larval Survival}

Daily survival rates of unfed larvae in different salinities (Series A) are shown in Tables 1-3. All larvae died on the 6 th or 7 th day after hatching. From survival rates prior to the day on which all larvae had died (Fig. $6)$, we conclude the following.

(1) If fertilized eggs were transferred to different salinities at the blastomere stage, the highest survival rate of larvae was found in the control group (27.2\% S), i.e., in a salinity identical with that at spawning. In

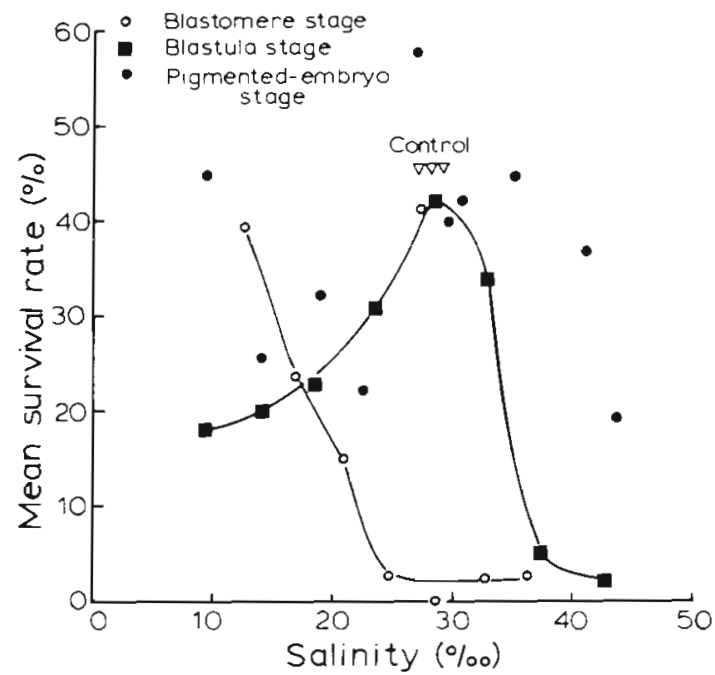

Fig. 6. Sillago sihama. Final survival rates of unfed larvae in different salinities; data from Tables $1-3$ addition, the lower the salinity, the longer the larvae survived.

(2) If fertilized eggs were transferred to different salinities at the blastula stage, the curve of larval survival rate was skewed to the left, maximum survival again occurring in the control group (28.2\% S). That is, larvae survived longer in lower than in higher salinities.

(3) If fertilized eggs were transferred to different salinities at the pigmented-embryo stage, the highest survival rate of larvae was found again in the control group. While survival rates fluctuated with the salinity change, there was no obvious correlation between survival rate and salinity change.

\section{DISCUSSION}

Water exchange of fertilized eggs with the external medium was proposed by Zotin (1965), Loeffler and Løvtrup (1970), Loeffler (1971) and May (1974a). Loeffler (1971) reported that there is a general tendency for the exchange coefficient to decrease as development progresses. On the other hand, the overgrowing embryo gradually regulates the concentration of the yolk, but full osmotic regulation in the embryo is not achieved until after the closing of the blastopore (Holliday and Jones, 1965). Reduced water exchange and increased osmoregulatory capacities at later developmental stages, suggest that fertilized eggs are more tolerant to salinity change. Holliday (1965) found the tolerance of developing fertilized eggs to be greater at later than at earlier stages. According to Holliday and Jones (1967), most of the fertilized plaice eggs died at the blastula or early-gastrula stage after transfer to extreme salinities. Similarly, our results show higher mortality rates after fertilized eggs were transferred to different salinities at the blastomere stage (Fig. 1), compared to those transferred at the blastula stage (Fig. 2). Eggs with pigmented embryos failed to hatch in salinities below $6 \% \mathrm{~S}$ (Fig. 5); similar results were obtained in mullet eggs ( $\mathrm{Hu}$ and Liao, 1979). It was suggested that abnormally developed musculature 
(Battle, 1929) or osmotic problems (May, 1975) may account for the inability of embryos to hatch in lower salinities.

Our results (Fig. 4) show that naturally spawned eggs are more tolerant to salinity change than are eggs from induced spawnings (Fig. 1), suggesting a difference in egg quality associated with the induction of spawning.

Fertilized eggs from spawners acclimated to lower salinities were more tolerant to salinity change (Fig. 5) than those without parental acclimation (Figs 1 and 4 ). Comparing hatching success in various salinities, May (1975) concluded that acclimation of spawning fish to a low salinity did not demonstrably affect the salinity tolerance of the eggs. Similarly, our results indicate that there were no differences in hatching success associated with parental acclimation; however, the percentage of pigmented-embryo formation was higher in lower salinities (Fig. 5) than in cases without parental salinity acclimation (Figs 1 and 4). Holliday and Jones (1967) indicate that, prior to their release, herring gametes are isosmotic with the blood of the parents, having a concentration approximately onethird that of seawater. Consequently, spawners acclimated to lower salinities should produce eggs different from those without parental salinity acclimation.

No matter at which stage the fertilized eggs were transferred to different salinities, the larvae hatched in the lowest salinities (12.6, 9.2, 9.4\% S) of Series A survived longest (Tables 1-3). Transfer of blastomere stage eggs to different salinities produced increasing larval survival rates with decreasing salinity down to $12.6 \%$ (Fig. 6). Similarly, it has been found that starving larvae of Sardinops melanostica (Nakai, 1962), Mugil cephalus (Sylvester et al., 1975; Hu and Liao, 1979), and Bairdiella icistia (May, 1975) survive longer in lower salinities. Herring larvae hatching in lower salinities usually have larger yolk sacs (Holliday and Blaxter, 1960; Alderdice and Velsen, 1971). However, from the freezing point depression of the body fluid of herring larvae (Holliday and Blaxter, 1960), of the yolk itself (Alderdice and Velsen, 1978), and the dry weight of B. icistia larvae in various salinities (May, 1974b), a larger yolk volume should correlate with higher water content. Salinity had only a minor effect on the rate of yolk absorption in B. icistia, yet yolk-utilization efficiencies were highest in lower salinities, i. e. those which approached levels isosmotic with the larvae (May, 1974b). In addition, in low salinities herring larvae showed lower activity levels and, presumably, reduced metabolic rates, thus extending their survival time in low salinities (Holliday, 1965).

In conclusion, fertilized eggs resulting from natural spawning were more tolerant to salinity change than those from induced spawning. Considering natural spawning, fertilized eggs could be incubated in salinities ranging from 10.6 to $38.1 \% \mathrm{~S}$ with a high hatching rate of over $50 \%$. Within the range of 10.6 to $38.1 \% \mathrm{~S}$, salinity variation exerts a minor effect in terms of percentage hatching success. Eggs at the blastomere stage were more sensitive to salinity change that those at later developmental stages. It is, therefore, suggested to transfer eggs as late as possible, wherever eggs are needed to be transferred from spawning to incubation tanks. Minimum osmotic work for larvae was also suggested to be associated with the maximum salinity tolerance (Alderdice et al., 1979).

Acknowledgements. We would like to express our thanks to the staff of the Fisheries Laboratory of the University of Tokyo for help in collecting breeders.

\section{LITERATURE CITED}

Alderdice, D. F., Velsen, F. P. J. (1971). Some effects of salinity and temperature on early development of Pacific herring (Clupea pallasi). J. Fish. Res. Bd Can. 28: $1545-1562$

A.lderdice, D. F., Velsen, F. P. J. (1978). Effects of short-term storage of gametes on fertilization of Pacific herring eggs. Helgoländer wiss. Meeresunters. 31: 485-498

Alderdice, D. F., Rao, T R., Rosenthal, H. (1979). Osmotic responses of eggs and larvae of the Pacific herring to salinity and cadmium. Helgoländer wiss. Meeresunters. 32: $508-538$

Battle, H. I. (1929). Effects of extreme temperatures and salinities on the development of Enchelyopus cimbrius (L.) Contr. Can. Biol. Fish. N. S. 5: 109-192

Hiyama, Y., Yasuda, F. (1961). Fishes of Japan (in Japanese). Koseisha Press, Tokyo

Holliday, F. G. T. (1965). Osmoregulation in marine teleost eggs and larvae. Calif. Coop. Oceanic Fish. Invest., Rep. 10: 89-95

Holliday, F. G. T., Blaxter, J. H. S. (1960). The effects of salinity on the developing eggs and larvae of the herring. J. mar. biol. Ass. U. K. 39: 591-603

Holliday, F. G. T., Jones, M. P. (1965). Osmotic regulation in the embryo of the herring (Clupea harengus). J. mar. biol. Ass. U. K. 45: 305-311

Holliday, F. G. T., Jones, M. P. (1967). Some effects of salinity on the developing eggs and larvae of the plaice (Pleuronectes platessa). J. mar. biol. Ass. U. K. 47: 39-48

Hu, F., Liao, I. C. (1979). The effect of salinity on the eggs and larvae of grey mullet, Mugil cephalus. ICES/ELH Symp./ RA: 6

Loeffler, C. A., Lovtrup, S. (1970). Water balance in the salmon egg. J. exp. Biol. 52: 291-298

Loeffler, C. A. (1971). Water exchange in the pike egg. J. exp. Biol. 55: 797-811

May, R. C. (1974a). Factors affecting buoyancy in the eggs of Bairdiella icistia (Pisces: Sciaenidae). Mar. Biol. 28: 55-59

May, R. C. (1974b). Effects of temperature and salinity on yolk utilization in Bairdiella icistia (Jordan and Gilbert) (Pisces: Sciaenidae). J. exp. mar. Biol. Ecol. 16: 213-225

May, R. C. (1975). Effects of temperature and salinity on fertilization, embryonic development and hatching in Bairdiella icistia (Pisces: Sciaenidae), and the effect of 
parental salinity acclimation on embryonic and larval salinity tolerance. Fish. Bull. U. S. 73 (1): 1-21

Nakai, Z. (1962). Studies relevant to mechanisms underlying the fluctuations in the catch of the Japanese sardine, Sardinops melanostica (Temminck and Schlegel). Jap. J. Ichthyol. 9: 1-113
Sylvester, J. R., Nash, C. E., Emberson, C. R. (1975). Salinity and oxygen tolerances of eggs and larvae of Hawaiian striped mullet, Mugil cephalus L. J. Fish Biol. 7: 621-629

Zotin, A. 1. (1965). The uptake and movement of water in embryos. Symp. Soc. Exp. Biol. 19: 365-384

This paper was presented by Professor M. Anraku; it was accepted for printing on October 2, 1980 